\title{
Preparation and properties of ferrite derived from iron oxidizing bacteria
}

\author{
ZHANG WenQiang, CAI Jun* \& ZHANG DeYuan \\ Bionic and Micro/Nano/Bio Manufacturing Technology Research Center, Beihang University, Beijing 100191, China
}

Received December 21, 2011; accepted February 6, 2012; published online May 6, 2012

\begin{abstract}
The growth characteristics of Sphaerotilus natans and Leptothrix discophora SS-1 (ATCC43182) were first used to fabricate the ferrite and manganese ferrite. The scanning electron microscopy (SEM), energy dispersive X-ray spectrometry (EDS), X-ray diffraction (XRD), and vibrant sample magnetometer (VSM) were used to make clear their morphology microstructure, chemical composition, crystal structure, and magnetostatic characteristic. The result showed that the hollow ferrite fibers were prepared successfully, whose crystal structures were close to $\alpha-\mathrm{Fe}_{2} \mathrm{O}_{3}$ and the average aspect ratio was over 50. Moreover, the soft magnetic manganese ferrite was fabricated with the saturation magnetization Ms at $25 \mathrm{emu} / \mathrm{g}$ and coercive force $H_{\mathrm{c}}$ at $796 \mathrm{~A} / \mathrm{m}$.
\end{abstract}

iron bacteria, ferrite, magnetic functional material, bio-growth forming

Citation: $\quad$ Zhang W Q, Cai J, Zhang D Y. Preparation and properties of ferrite derived from iron oxidizing bacteria. Chin Sci Bull, 2012, 57: 2470-2474, doi: $10.1007 /$ s11434-012-5192-1

Biological manufacturing is an emerging cross-disciplinary, which could achieve the efficient and environmentally friendly fabrication of micro/nano functional materials or devices [1,2]. Bio-growth forming is a new method to obtain the required functional materials or products with the direct use of the microbial growth characteristics [1]. For example, the microbe is used to pharmaceutical fermentation, or the magnetotactic bacteria is used to synthesize single domain $\mathrm{Fe}_{3} \mathrm{O}_{4}[3,4]$.

Currently, in the areas of materials, the study of magnetic materials represented by ferrite has become a hotspot, and it is widely used in the manufacture of new high-tech products, like electromagnetic absorbing materials, magnetic recording materials, magnetic fluids, catalytic materials, coating or paint $[5,6]$. It was shown that iron bacteria are widespread in various types of nature waters, which have the capacity of oxidizing and depositing ferrous ions and manganese ions in water efficiently. This microbe could be directly used to obtain composites with a variety of shapes such as fiber, tube and film [7-16] and has the potential to fabricate

*Corresponding author (email: jun_cai@buaa.edu.cn) the ferrite materials. Compared to traditional chemical synthesis [5], there may be a breakthrough in the aspects of physical control, particle reunion and industrialization.

In this paper, according to the enrichment and deposition mechanism of iron and manganese [7-12], the sediment composition, the microstructure characteristics [15] and other basic research of iron bacteria, the Sphaerotilus natans which were separated from activity mud of Xiamen sewage treatment plant and the Leptothrix discophora which was purchased from ATCC, were used to deposit the iron and manganese ions respectively. The Sediments were collected and heat treated at high temperature to obtain the ferrite. And then the product morphology and static magnetic properties were characterized.

\section{Materials and methods}

\subsection{Materials and formulations}

The Sphaerotilus natans were isolated and cultured from the Xiamen sewage treatment plant [13,14], then the Leptothrix discophora was purchased from ATCC (ATCC 43182). 


\subsection{Experimental process}

Ferrite fabricated by the Sphaerotilus natans growth: According to Table 1, $0.8 \mathrm{~L}$ urea medium was configured. After high-temperature sterilization, the activated Sphaerotilus natans were vaccinated. Then the medium was cultured for $24 \mathrm{~h}$ at the constant temperature of $27^{\circ} \mathrm{C}$ so as to obtain a great number of Sphaerotilus natans. In order to prevent the bacteria from being killed as a result of a great change of $\mathrm{pH}$, the iron deposition medium, after UV sterilization, needed to be added to the mixture in an equal amount by ten times. In this process, the $\mathrm{pH}$ was kept between 6.5 and 7.0 by dropping $1 \mathrm{~mol} / \mathrm{L}$ of sodium hydroxide and $1 \mathrm{~mol} / \mathrm{L}$ hydrochloric acid solution to the medium. Place the culture medium in the incubator of $27^{\circ} \mathrm{C}$ for 50 continuous days. After that remove it and the sediment was obtained for observation and testing by repeated centrifugation, washing, and vacuum drying. In addition, put a small amount of powder into the muffle furnace, and heat-treat it at $900^{\circ} \mathrm{C}$ for $1 \mathrm{~h}$. After that, cool down the sample in the furnace to the room temperature, and remove it for use.

Ferrite fabricated by the Leptothrix discophora growth: The Leptothrix discophora was inoculated to pre-configured ATCC medium at $2^{\circ} \mathrm{C}$ by $150 \mathrm{r} / \mathrm{min}$, activated and enrichment cultured for $72 \mathrm{~h}$, and with the $\mathrm{pH}$ value $(\mathrm{pH} 7)$ adjusted every $12 \mathrm{~h}$ with $\mathrm{NaOH}$; then take $100 \mathrm{~mL}$ enriched culture medium and add to the pre-configured MMS medium, adjust $\mathrm{pH}$ to 6.0 ; prepare $\mathrm{FeSO}_{4}$ and $\mathrm{MnSO}_{4}$ mixed solution $\left(\mathrm{Fe}^{2+}, \mathrm{Mn}^{2+}\right.$ ion ratio is $3: 1,2: 1$, and $1: 1, \mathrm{Mn}^{2+}$ ions concentration of $1 \mathrm{~mol} / \mathrm{L})$, and after filter-sterilized,

Table 1 The formula table of different medium ${ }^{\text {a) }}$

\begin{tabular}{|c|c|c|c|c|}
\hline Name & $\begin{array}{l}\text { ATCC } \\
\text { medium } \\
(\mathrm{mg})\end{array}$ & $\begin{array}{l}\text { MMS } \\
\text { medium } \\
(\mathrm{mg})\end{array}$ & $\begin{array}{l}\text { Urea } \\
\text { medium } \\
(\mathrm{mg})\end{array}$ & $\begin{array}{l}\text { Iron deposition } \\
\text { medium } \\
(\mathrm{mg})\end{array}$ \\
\hline Peptone & 500 & & & \\
\hline Urea & & & 500 & 500 \\
\hline Yeast extract & 500 & & & \\
\hline Glucose & 500 & & 1000 & 1000 \\
\hline Pyruvate & & 240 & & \\
\hline $\mathrm{MgSO}_{4} \cdot 7 \mathrm{H}_{2} \mathrm{O}$ & 600 & 35 & 50 & 50 \\
\hline $\mathrm{CaCl}_{2} \cdot 2 \mathrm{H}_{2} \mathrm{O}$ & 70 & 30 & & \\
\hline HEPES & 3570 & & & \\
\hline $\mathrm{MnSO}_{4} \cdot \mathrm{H}_{2} \mathrm{O}$ & 17.0 & & & \\
\hline $\mathrm{FeSO}_{4}$ & & 0.15 & & \\
\hline$\left(\mathrm{NH}_{4}\right)_{2} \mathrm{SO}_{4}$ & & 120 & & \\
\hline $\mathrm{KNO}_{3}$ & & 15 & & \\
\hline $\mathrm{NaHCO}_{3}$ & & 0.84 & & \\
\hline $\mathrm{KH}_{2} \mathrm{PO}_{4}$ & & 0.70 & & \\
\hline Vitamin $B_{12}$ & & 0.002 & & \\
\hline $\mathrm{K}_{2} \mathrm{HPO}_{4}$ & & & 100 & 100 \\
\hline $\mathrm{Fe}_{2}\left(\mathrm{SO}_{4}\right)_{3}$ & & & & 2280 \\
\hline Distilled water (L) & 1 & 1 & 1 & 1 \\
\hline
\end{tabular}

a) With $\mathrm{NaOH}$ to adjust $\mathrm{pH}$ : ATCC mediun, $\mathrm{pH}$ 7.3; MMS mediun, $\mathrm{pH}$ 6.0; urea medium, $\mathrm{pH} 7.0$; and iron deposition medium, $\mathrm{pH} 6.5$.
$20 \mathrm{~mL}$ solution was added to the three culture medium respectively to adjust $\mathrm{pH}$ to 6 ; add every $24 \mathrm{~h}$ for 10 consecutive days; the medium was left to stand at $27^{\circ} \mathrm{C}$ for a week, and then it was repeatedly centrifugated, washed, and vacuum dried in order to obtain sediment; finally, place the sediment into the muffle furnace, and heat-treat it at $900^{\circ} \mathrm{C}$ for $1 \mathrm{~h}$. After that, cool down the sample in the furnace to the room temperature, and remove it for use.

\subsection{Properties characterization}

XSY-1 optical microscope plus Cannon 450 photographic camera, CS3400 scanning electron microscope (SEM), and Apollo300 Field emission scanning electron microscope (FESEM) were used to observe and study the cell form, while Oxford Link 860 energy dispersive spectrometer (EDS) and D/Max 2200 PC automatic X-ray diffraction (XRD) were used respectively to analyse the composition and the phase structure. The magnetic properties were evaluated on a vibrating sample magnetometer (VSM, JDM-13).

\section{Results and discussion}

To fabricate the fiber and iron oxide using the growth of iron bacteria, the Sphaerotilus natans and the Leptothrix discophora first needed enrichment culturing.

Figure 1 shows the optical photograph of Sphaerotilus natans $(1.8-2.3 \mu \mathrm{m} \times 10-250 \mu \mathrm{m})$. In Figure 1a, with a few sheath adhering in bundles, pseudo-single-branch and cell vacancy appeared. In Figure 1b, single iron oxidizing bacteria cells $(\mathrm{A})$, short rod-shaped $(1.0-2.5 \mu \mathrm{m} \times 1.5-5.8 \mu \mathrm{m})$, were found around the clothing sheath with more cells vacancy (B).

Figure 2 shows the optical photograph of Leptothrix discophora $(0.5-1 \mu \mathrm{m})$ with the ATCC medium enrichment culture. Figure $2 \mathrm{a}$ shows that the single bacterial cells account for a large percentage, with obvious agglomeration; while in Figure $2 \mathrm{~b}$, there is a marked absence of clothing and cell sheath. Although Leptothrix discophora (ATCC43182) itself does not have clothes sheath [9], but in the latter part of the training process, there will be variations in the cell, thus forming clothing sheath.
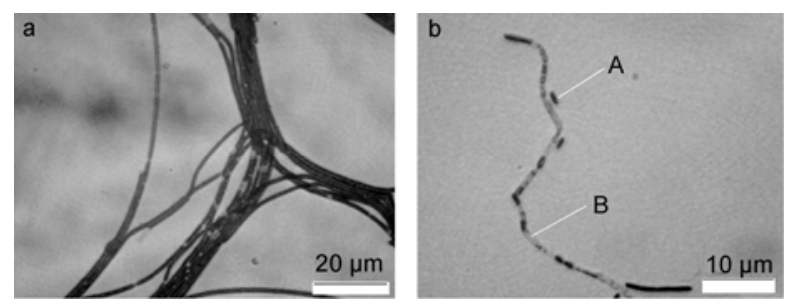

Figure 1 Optical photograph of Sphaerotilus natans. a, Enrichment culture for $24 \mathrm{~h}$; b, enrichment culture for $72 \mathrm{~h}$; A, a single cell of Sphae rotilus natans; $\mathrm{B}$, a cell vacancy. 

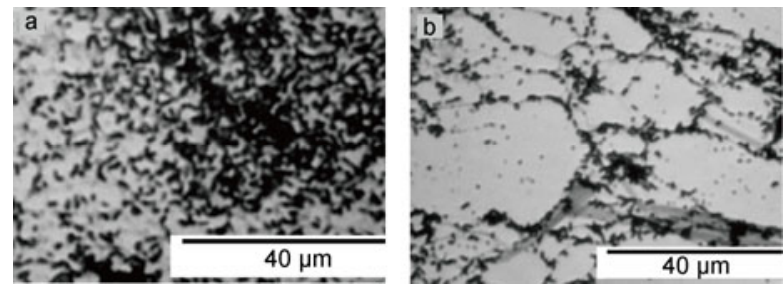

Figure 2 Optical photograph of Leptothrix discophora. a, Cell-free state; b, clothing sheath cells forming.

The iron deposition medium and MMS media were used further to inoculate the Sphaerotilus natans and the Leptothrix discophora, respectively. After $24 \mathrm{~h}$, yellow or brown sediment began to appear in the culture medium. Several weeks later, the sediment was basically stable. Figure 3 shows the overview of the sediment sample which was separated from the iron deposition medium, filamentous fibers (A) occupying most of the view with some micro particulate particles (B). Figure 3a is low magnification SEM micrographs of Sphaerotilus natans sediment, in which the proportion of iron fibers (A) in products is more than $90 \%$. The fibers maintained the shape of the Sphaerotilus natans (fibrous and curved), and most of the iron fibers did not have a smooth outer layer. Figure $3 b$ is high magnification SEM image of one single ferrite fiber, and from its scale we can see that the fiber diameter was $2.18 \mu \mathrm{m}$, and that the fiber aspect ratio was about 50 . Figure $3 \mathrm{c}$ gives the enlarged image of the broken section of the fiber. It is clear that the fiber was hollow inside, which was consistent with the deposition theory of iron bacteria. Figure 4 is SEM micrographs of manganese and iron oxide which was deposited by Leptothrix discophora. Figure 4a shows that the obtained oxides were nano-particles with the diameter changing from tens to hundreds of nanometers (C). It was observed that Leptothrix discophora (D) cells remained in the nano-particles, which is the further evidence of Leptothrix discophora growth leading to iron and manganese oxides in the surrounding sediments; while Figure $4 \mathrm{~b}$ shows the obtained

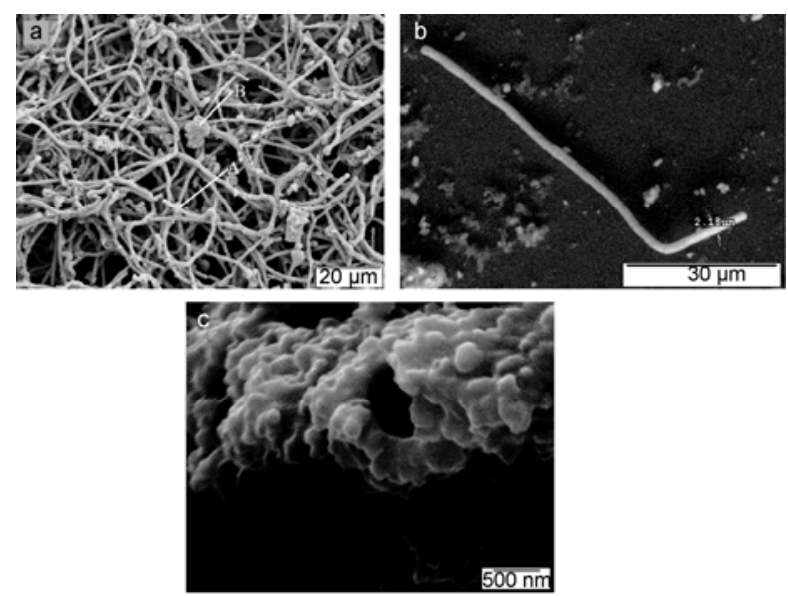

Figure 3 SEM images of iron oxide fiber prepared by Sphaerotilus natans. a, Gathered fibers; $b$, single fiber; $c$, the broken section of the fiber.
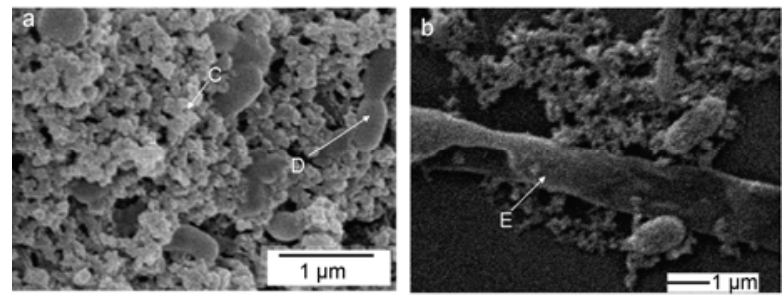

Figure 4 SEM images of manganese and iron oxide prepared by Leptothrix discophora. a, Manganese and iron oxide; b, mixture of manganese and iron oxide fiber and particles.

oxide composite still contained a small number of hollow fibers $(\mathrm{E})$, with the diameter of $1-2 \mu \mathrm{m}$, and the aspect ratio of more than 50, indicating that variation bacteria with sheath ability could form a hollow ferromanganese oxide fibers, and Leptothrix discophora cell was out of the sheath.

EDS was used to analyze the chemical composition of the SEM sample, the results showed that the major component of the Sphaerotilus natans sediments was iron oxide, and the main content of the Leptothrix discophora sediments was ferromanganese oxides, whose EDS spectra was shown in part in Figure 5. Figure 5a is the EDS spectra of iron fibers which were the deposition of the Sphaerotilus natans. The result showed that the main components of the fibers were $\mathrm{Fe}$ and $\mathrm{O}$, with the $\mathrm{Fe} / \mathrm{O}$ atomic ratio of 0.77 throughout the statistical analysis on the whole region of iron oxides and a point of the fiber. It is inferred that fiber deposited by the Sphaerotilus natans was an iron oxide fiber, Figure $5 b$ and $c$ is the average EDS spectra of the sediment produced by Leptothrix discophora growing $\left(\mathrm{Fe}^{2+}\right.$ : $\mathrm{Mn}^{2+}$ for the 2:1 and 1:1). The result showed that the main component of sediments were $\mathrm{Fe}, \mathrm{Mn}$ and $\mathrm{O}$. By comparing the deposition product of $\mathrm{Fe}, \mathrm{Mn}$ atomic ratio and the addition of iron, manganese ion concentration ratio, they were found to be basically the same (add the ratio of the original $3: 1,2: 1,1: 1$; and test the average ratio of $3.1: 1,1.9: 1,1: 1)$. Further, it is confirmed that the use of Leptothrix discophora could not only prepare ferromanganese oxides, but also control the ratio of manganese and iron in the product.

Figure 6 is the typical XRD diffraction pattern of iron bacteria deposits before and after treatment. There are two broad peaks in the graph in Figure 6a, with $d$-values corresponding to $d=0.25 \mathrm{~nm}$ and $d=0.15 \mathrm{~nm}$. The major components were considered to be poor crystalline iron oxide. The XRD pattern of the hydrated ferric oxide fibers is similar to Lepidocrocite, $\mathrm{FeO}(\mathrm{OH})$. Figure $6 \mathrm{~b}$ is the XRD diffraction pattern of the amorphous iron oxide fiber which was heat-treated at $900^{\circ} \mathrm{C}$ for $1 \mathrm{~h}$. There are many obvious crystallization peaks, indicating that high-temperature treatment results in crystalline phase-change of the amorphous hydrated ferric oxide fibers to crystalline iron oxide fibers. As is shown in Figure 6b, the sample showed strong diffraction peaks matching well with the standard data for $\alpha-\mathrm{Fe}_{2} \mathrm{O}_{3}$ (JCPDS79-1741). According to Scherrer formula, their average grain size is $41 \mathrm{~nm}$. And Figure $6 \mathrm{c}$ is the XRD 

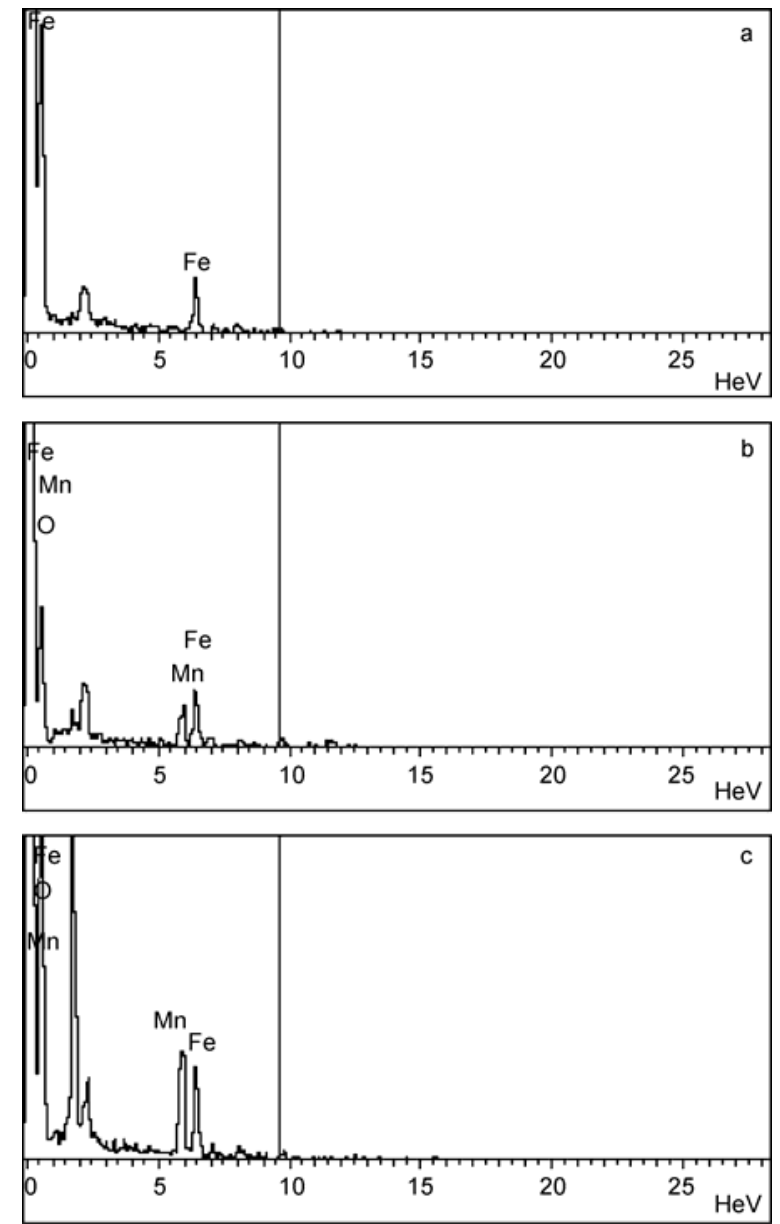

Figure 5 EDS analysis of iron bacteria sediment. a, Iron oxide fiber prepared by Sphaerotilus natans; b, c, the manganese and iron oxide prepared by Leptothrix discophora.

diffraction pattern of ferromanganese oxide deposited by Leptothrix discophora which was heat-treated at $900^{\circ} \mathrm{C}$ for 1 h. Figure $6 \mathrm{c}$ shows obvious characteristic diffraction peaks, indicating good crystalline. As is shown in Figure 6c, the strong diffraction peaks of the sample matched well with $\mathrm{MnFe}_{2} \mathrm{O}_{4}$. According to Scherrer formula, their average grain size is $45 \mathrm{~nm}$. The XRD results indicated that the use of iron bacteria deposits to fabricate spinel ferromanganese oxide is feasible.

After heat treatment, the static magnetic properties of iron oxide fiber and manganese ferrite were characterized by vibrating magnetometer respectively. Figure 7 a shows the saturation magnetization of iron oxide fibers was 0.4 emu/g, while the coercivity was $1.18 \times 10^{5} \mathrm{~A} / \mathrm{m}$, which belongs to anti-ferromagnetic material; while Figure $7 \mathrm{~b}$ shows that the manganese ferrite saturation magnetization reached to $24 \mathrm{emu} / \mathrm{g}$ and the coercivity was $796 \mathrm{~A} / \mathrm{m}$, with good soft magnetic properties. Initial analysis showed that the performance difference of iron oxide fiber and manganese ferrite prepared by the deposition of iron bacteria was mainly due to the fact that the iron oxide belongs to a- $\mathrm{Fe}_{2} \mathrm{O}_{3}$ with the no magnetic body-centered cubic structure. With the
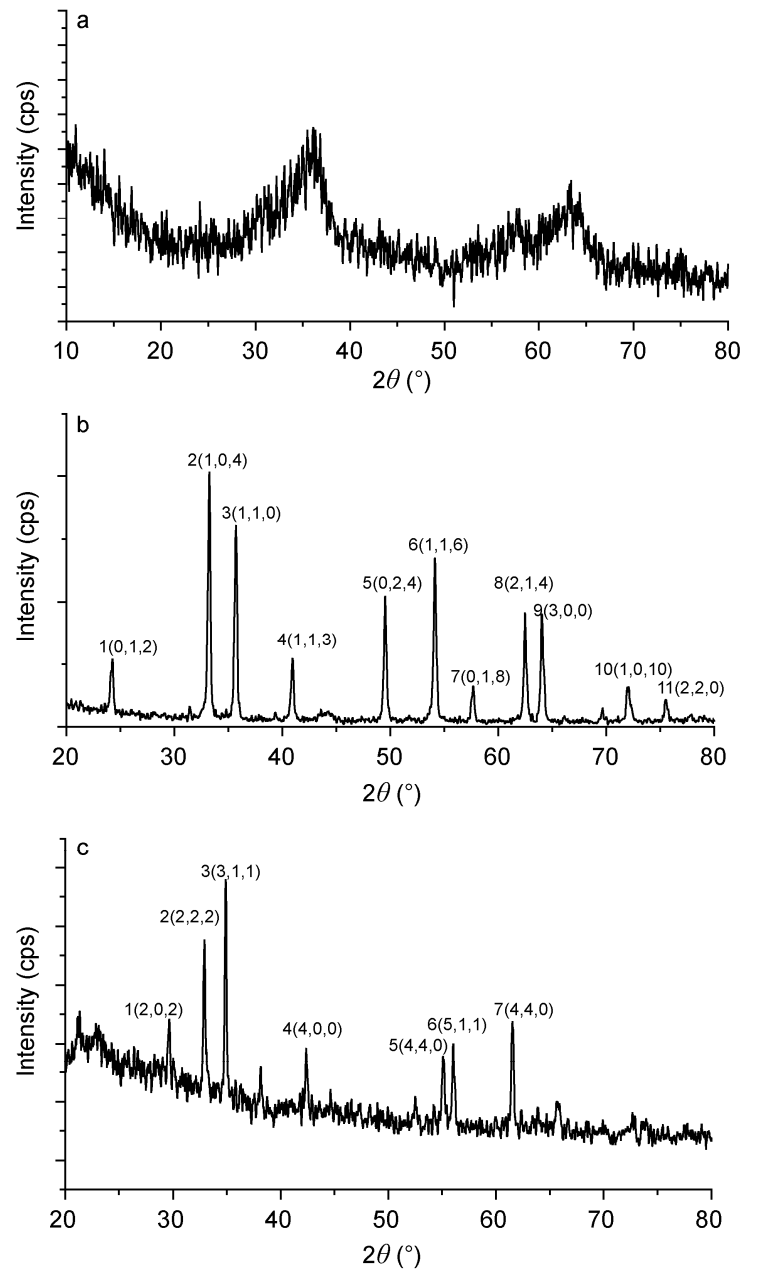

Figure 6 XRD diffraction pattern of iron bacteria sediment. a, Iron oxide fiber prepare by Sphaerotilus natans; b, the iron oxide fiber with heattreatment; $c$, the manganese and iron oxide with heat-treatment.

deposition of Mn ions, the overall structure of the lattice changed into a spinel-type, resulting in the production of soft magnetic properties, which are consistent with characterized results by XRD and are consistent with the reported properties of manganese ferrite as well [5]. It proved that the feasibility of ferromanganese oxidizing bacteria in preparing manganese ferrite by co-deposition.

\section{Conclusions and perspectives}

In this paper, the fibrous amorphous iron oxides, with the diameter of $1-3 \mu \mathrm{m}$, the aspect ratio of over 50 , and the $\mathrm{Fe} / \mathrm{O}$ atomic ratio of 0.77 , were obtained by culturing the sheath iron bacteria. After heat treatment, their main component was $\alpha-\mathrm{Fe}_{2} \mathrm{O}_{3}$ and the average grain diameter was 41 $\mathrm{nm}$. Furthermore the composite, with the content of iron and manganese controlled, was prepared successfully by biomanufacturing using Leptothrix discophora with the manganese and iron oxidative capacity. After heat treatment, soft magnetic manganese ferrite was obtained with saturation 

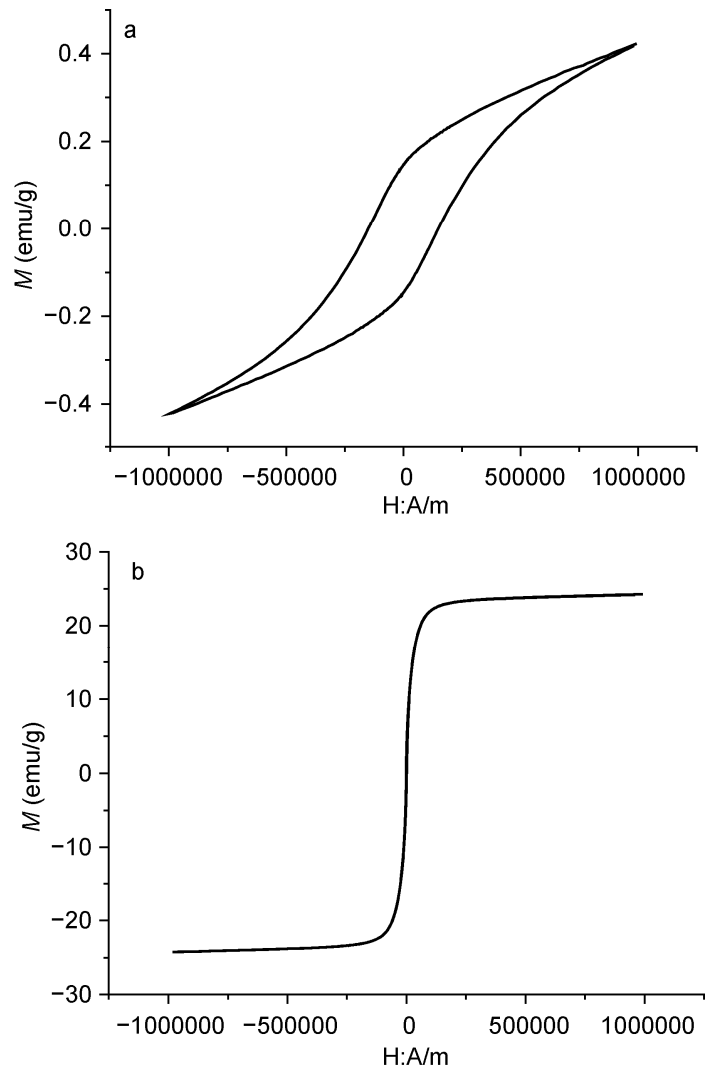

Figure 7 Hysteresis loops of iron bacteria sediment. a, Iron oxide fiber; b, manganese ferrite.

magnetization of $25 \mathrm{emu} / \mathrm{g}$ and coercivity of $796 \mathrm{~A} / \mathrm{m}$. This paper extends the application field of iron bacteria and provides a new method to preparing light and special shaped ferrite. The next step will be in-depth study of the control method of ferromanganese content, the relationship between static magnetic properties and the dynamic magnetic properties, and a try to fabricate soft ferrite and hollow fiber tube by use of iron bacteria.

This work was supported by the National Natural Science Foundation of China (50805005), the National High-tech R\&D Program of China (2009AA043804), the Foundation for the Author of National Excellent
Doctoral Dissertation of China (2007B32), and the Innovation Foundation of BUAA for PhD Graduates.

1 Zhang D Y, Cai J, Li X, et al. Bioforming methods of bionic manufacturing. Chin J Mech Eng, 2010, 46: 88-92

2 Zhang D Y, Zhang W Q, Cai J. Magnetization of microorganism cells by thermal decomposition method. Sci China Tech Sci, 2011, 54: $1275-1280$

3 Sun X L, Liu W W, Zhang Y Z, et al. Progress in studies on magnetotactic bacterium. Chin J Microecol, 2011, 23: 570-573

4 Schüler D. Genetics and cell biology of magnetosome formation in magnetotactic bacteria. FEMS Microbiol Rev, 2008, 32: 654-672

5 Zhang P P, Han C H, Cheng J P, et al. Effect of La doping on magnetic properties of ferrite prepared from ocean manganese nodules. Chin J Inorg Chem, 2008, 24: 307-310

6 Wang X H, Li X J, Zhang Y J, et al. Experiment research of nano manganese ferrite powders prepared by detonation method. Chin $\mathrm{J}$ High Pressure Phys, 2007, 21: 173-177

7 Learman D R, Wankel S D, Webb S M, et al. Coupled biotic-abiotic $\mathrm{Mn}(\mathrm{II})$ oxidation pathway mediates the formation and structural evolution of biogenic Mn oxides. Geochim Cosmochim Acta, 2011, 75: 6048-6063

8 Sawayama M, Suzuki T, Hashimoto H, et al. Isolation of a Leptothrix strain, OUMS1, from ocherous deposits in Groundwater. Curr Microbiol, 2011, 63: 173-180

9 El Gheriany I A, Bocioaga D, Hay A G, et al. An uncertain role for $\mathrm{Cu}(\mathrm{II})$ in stimulating $\mathrm{Mn}(\mathrm{II})$ oxidation by Leptothrix discophora SS-1. Arch Microbiol, 2011, 193: 89-93

10 Gheriany I A E, Bocioaga D, Hay A G, et al. Iron requirement for Mn(II) oxidation by Leptothrix discophora SS-1. Appl Environ Microb, 2009, 75: 1229-1235

11 Spring S, Dworkin M, Falkow S, et al. The genera Leptothrix and Sphaerotilus. Prokaryotes, 2006, 5: 758-777

12 David E, William C G. Isolation, cultural maintenance, and taxonomy of a sheath-forming strain of Leptothrix discophora and characterization of manganese-oxidizing activity associated with the sheath. Appl Environ Microb, 1992, 58: 4001-4010

$13 \mathrm{Xu}$ X P, She C X, Lin Y X, et al. Isolation, identification and preservation of iron-oxidizing sheathed bacteria from water. Chin J Appl Environ Biol, 2003, 9: 313-317

14 van Veen W L, Mulder E G, Deinema M H. The SphaerotilusLeptothrix group of bacteria. Microbiol Rev, 1978, 42: 329-356

15 Hashimoto H, Yokoyama S, Asaoka H, et al. Characteristics of hollow microtubes consisting of amorphous iron oxide nanoparticles produced by iron oxidizing bacteria, Leptothrix ochrace. J Magn Magn Mater, 2007, 310: 2405-2407

16 Yang H, Ji J, Zhong J, et al. Investigation and application of biological manganese removal technology. Environ Sci Technol, 2008, 8: $38-43$

Open Access This article is distributed under the terms of the Creative Commons Attribution License which permits any use, distribution, and reproduction in any medium, provided the original author(s) and source are credited. 